\title{
Increasing personalisation in scientific college courses
}

In the U.S., women and
minorities are severely
underrepresented in the science,
technology, engineering,
and maths (STEM) workforce.
Nationiwide and only 40\%
of students who enrol in
a STEM course complete
their training. Dr Aditi Pai is
exploring the challenge of
making undergraduate biology
more engaging with the aim
of increasing student success.
Instead of the traditional
approach which uses textbook
examples of evolution, natural
selection, migration, and
genetics, Dr Pai's classes focus
on personalisation and the
reallifie histories of her students
at Spelman College.

In the U.S., building a diverse science

This lower graduation rate is resulting suggested that one million qualified of women and minorities in the STEM workforce. For example, in the workforce

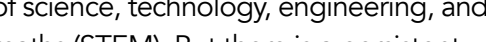
problem problem with retaining students in these disciplines, and data suggests that only $40 \%$ of students who enrol in a ST complete their training.

Introductory science courses are one of the biggest points of loss, partly because they are often designed as gatekeeper courses where failure is expected from a large percentage of students. Studies show that many students leave STEM courses because they feel alienated and disenfranchised by the fact-orientated culture of sciences. Students often report feeling isolated by large-enrolment classes and the abstract nature of course materias which seems devoid of relevance in the context of their future lives.

These negative influences have a disproportionate effect on the college trajectories of women and minority students. Wh the STEM minorties make yet they account for just 45\% of STEM degree holders. itself, African Americans comprise 13\% of the total U.S. workforce, but only $3 \%$ all these reasons, educators in STEM faculties must focus on decreasing

\section{PERSONALISATION IN GENETICS} AND GENEALOGY

In response to these statistics, Aditi Pai $\mathrm{Ph}$. , is working to increase student interest in genetics and evolution. Dr Pais revolutionary teaching method, which was inspired by a TV show, "Finding your roots," focuses on personalisation and gives students the opportunity to learn the fundamentals of biology by exploring their own DNA. Through the genetics and genealogy project at Spelman College, students are learning about themselves while they learn science.

$$
\text { (1) }
$$
of the technical or STEM workforce. For which As part of the program, students are$$
\begin{array}{ll}
\text { microscope on themselves } & \text { is the consideration of the relevance } \\
\text { and interest to students. }
\end{array}
$$

Previously, within the boundaries of traditional curricula, it has been difficult to execute this student-centred learning method. However, advancements in educational technology now facilitate the delivery of content according to students' preferences. Despite this, personalised learning is still a relatively uncommon approach to rectifying the in STEM subjects.

\section{A UNIQUE APPROACH}

TO STEM CURRICULA

Dr Pai, an evolutionary biologist and faculty member of Spelman College's chogy department, is explong the challenge of making undergraduate
biology more engaging for students.

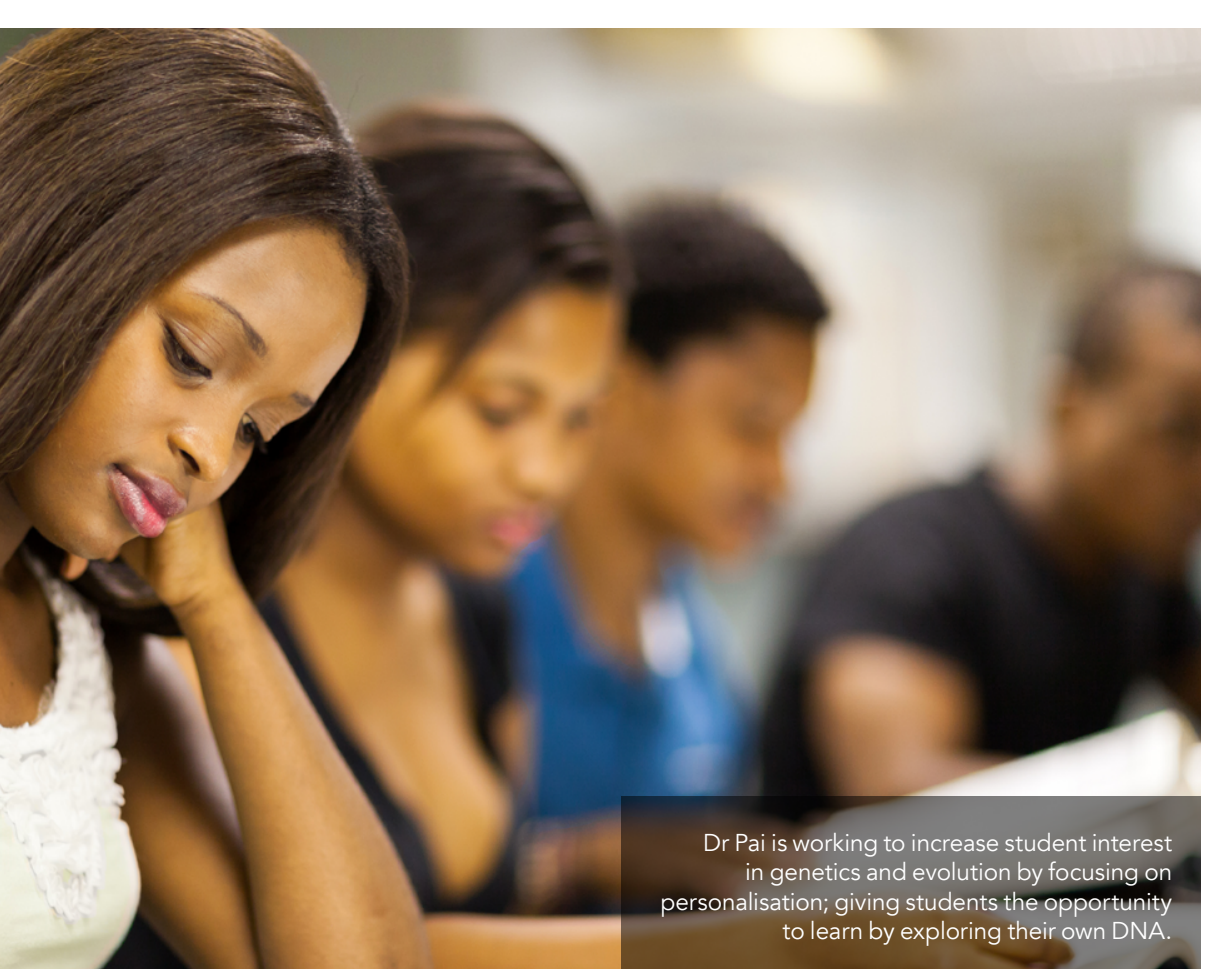

She is doing this by personalising the learning experience for every student, with increasing the motivation to undertake science major. The program introduces

strong focus on interdisciplinary learning which makes it the ideal institution for $D$ Pai's program to take place. Biology is one of the largest majors at Spelman, with freshmen enroling in first-year biology

African Americans comprise 13\% of the total US workforce but only $3 \%$ of the technical or STEM workforce.

while looking at human variation and health. Instead of the traditional approach which uses textbook examples of gentics, Dr Pai's classes focus ontion, and life histories of her students.

This unique undergraduate biology program is being conducted at Spelman College, and more recently at two other
historically black colleges (Morehouse College and North Carolina A\&T), in association with Joe Graves, Kelsie Bernot, Wallace Sharif, Anna Powolny, and Gene McGinnis. A similar program for middle school students is run by Nina Jablonski (Penn State) and her team small, selective, historically black college for women in Atlanta, Georgia. Spelman has had a positive impact on increasing the STEM workforce. The college places each year. Yet, of the 110 students who 65 in the freshman biology class, only $25-35 \%$ of stud biogy majors and almost of their introductory core sequence.

\section{MODERN GENETICS} AND EVOLUTION

Dr Pai and colleagues piloted an introductory biology class where the course focused on the personalisation of materials to each individual student. The program, which was funded by a National Science Foundation grant, aims to promote science education through an interdisciplinary approach. Its of disadvantaged and minority students in science. By using students' personal Nff, the tean is working to increase effort and excitement with the ultimate in the STEM workforce. objective is to facilitate the engagement 
Investigate. Explore. Discover. Create!

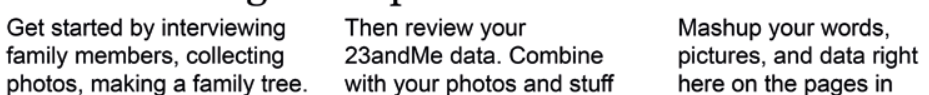
family members, collecting
photos, making a family tree.

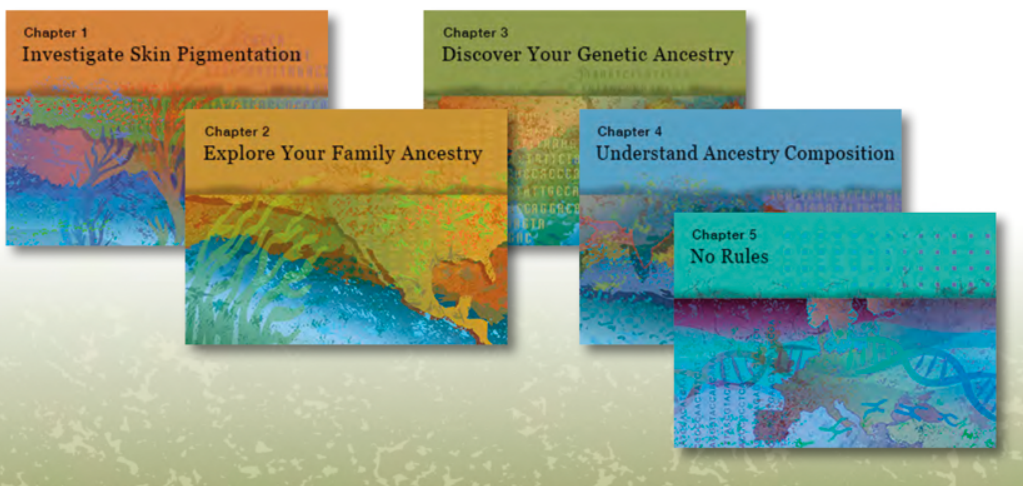

This approach focuses on genetics engagement while providing students with a strong knowledge foundation on which they can build their future STEM education. In the class, students learn the basics of genetics and evolution by using genetic testing kits to explore their own DNA, or with a DNA sequence of an

see science in a much more personalised way. And, the course has proven itself to be an excellent tool for achieving the goa of inclusive excellence in STEM subjects.

\section{ROVED ENGAGEMENT}

AND OUTCOMES

project suggests that students were

Dr Pai's unique approach to Spelman's introductory biology course focuses on genetics and genealogy in an effort to increase engagement.

online avatar. This exercise was designed their own personal narrative using biological and historical tools Genetics,

DNA, personal genealogy and family history combine to answer the quily "Who am I?" Students in Dr Pai's class conduct a 'Study of Me,' where they lea the principles of inheritance, modern genetics, and evolution. Other unique features of Dr Pai's curriculum include is interdisciplinary approach - using history and sociology to give biologica data context. The program is also novel in its use of visualisation tools for understanding genetic data.

Through Dr Paiis personal genomics program, students who once viewed lives have been given the opportunity to enthusiastic about a personalised curriculum in biology classes. Eighty-nin class that used their individual genetic data, and $65 \%$ of students said that they would be more likely to enrol in a biology course which offered DNA testing than one without this option. Overall, studen reported that they were "very excited" about the specific elements that would be incorporated in the personalised genetics and genealogy course.

In addition to students reporting high levels of engagement, Dr Pai and her outcomes for students who studied biology through their own DNA. Resuls in the success rates of students who colleagues also demonstrated improve

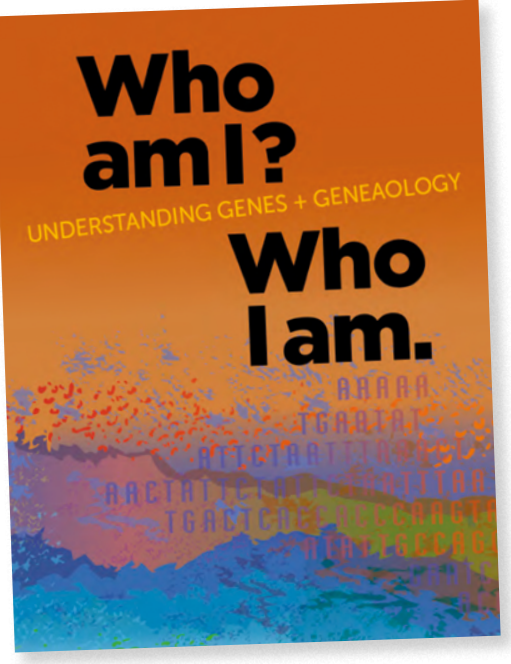

Spelman College students conduct a 'Study
of me' where they learn the principles of of me' where they learn the principles of
inheritance, modern genetics and evolution.

participated in the personal genomic over $90 \%$ of students who participated passed the course, compared to just $50 \%$ of those who did not take part. The withdrawal rate was lower in those students who used the personal genomic kits, and growth was also noted in students' engagement in classes using personal genomics. Students' learning gains also increased, and there was a clear improvement in their general knowledge, understanding of skin pigmentation, and of human evolution and speciation. Overall, around a 20\% knowledge increas was seen after the genes and genealogy dules had been completed.

Approximately 220 underrepresented male students have benefitted from this personalised course during its first three years, and hundreds of other students benefitted from attending talls from experts on 'Race, Genetics, and Genealogy.' Additionally, more than on dozen faculty members at three historically black colleges and universities are eceiving training via faculty developmen workshops. Dr Pai predicts that the biggest impact will likely be from the dissemination of the gene and genealogy modules and supplementary talks, and the DNA Portrait Builder app, which has the potential to be adopted by faculty anywhere.

To find out more about the Genes and Genealogy Project at Spelman College, vist

\section{Behind the Research}

\section{Dr Aditi Pai}

E: apai@spelman.edu T: $+14042705778 \quad$ W: https://www.youtube.com/watch?v=KOWMH69b7EY

\section{Research Objectives}

The Genes and Genealogy Project at Spelman College is The science education through an interdisciplinary approach
using genealogy, and for students to engage in biology concepts through exploring their personal DNA.

\section{Detail}

Dr Aditi Pai

269 Science Building

Silogyy Department,

350 Spelman Ln,

Atlanta, GA 30314

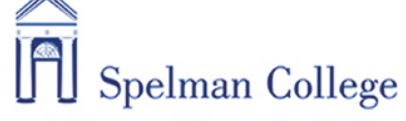

Bio

Aditi Pai is an evolutionary biologist and faculty in Biology Department at Spelman College. In 2018, she was selected for the Governor's Teaching Fellowship by the University of Georgia, Athens. Pai has served as Vice Chair of Biology and is currently co-director of Spelman's Teaching Resource and Research Center.

Funding

tional Science Foundation

\section{Collaborators}

sie Bernot, North Carolina A\&

- Wallace Sharif, Morehouse College

- Anna Powolny, Gene McGinnis, Jennifer Kovacs and Yonas

Tekle, Spelman College

- Lynn Fellman, Fellman Studio

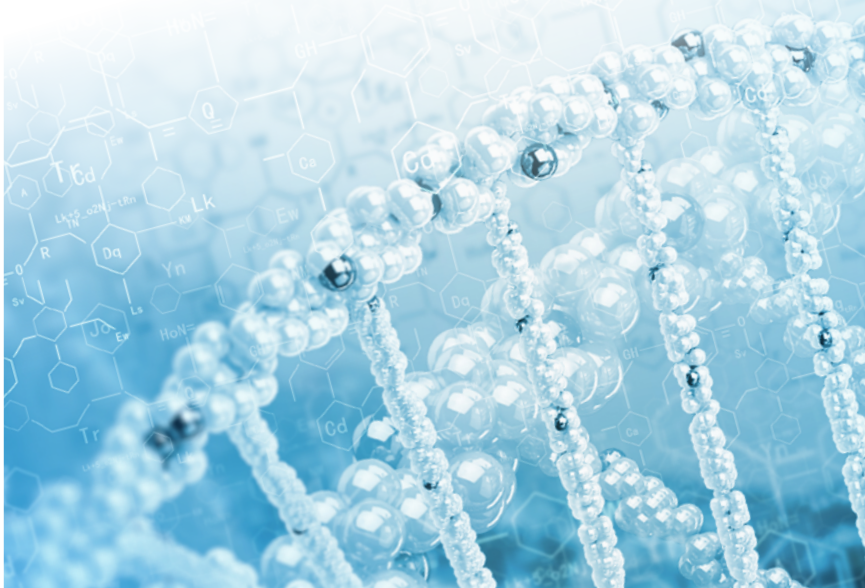

References

The Genes and Genealogy Project at Spelman College, YouTube video https:///www.youtube.com/ watch?v=KOWMH69b7EY

Spelman College News, 2015. “Aditi Pai, Ph.D., Leads Genealogy Program with Students Tracing Ancestry." hhtpps://spelman.edu/about-us/newsassociate-professor-of-biology

Penn State Digital, WPSU. Finding your roots: the seedlings. Dig into ancestry with genetics and genealogy. https://wpsu. psu.edu/digital/finding-your-roots-the-seedlings/

\section{Personal Response} What is a realistic goal for women and minority
representation in the STEM workforce in the next

II From 1990 to date, STEM fields have seen an overal howeve in representation of women in the workforce, particular STEM field. For example, in the health sciences, women now comprise $74 \%$ of the workforce whereas only $14 \%$ of Engineering workforce are women (Source: Pew Research Center, 2018). Similarly, Blacks and Hispanics continue to be underrepresented in
(Source: Pew Research Center, 2018)

Studies reveal that workers from underrepresented groups state 1) lack of access to education, 2) lack of as some of the major factors that hinder their progress in STEM fields. Therefore, the best way to ensure that the STEM workforce is representative of the nation's population is to focus on eliminating the above sources of bias from workplaces and institutions of higher education. A key more inclusive, for example, through curriculum reform such as personalisation. 